\title{
Evaluation of impact of participatory Forest Management on forest cover of West Bengal through real time monitoring using Remote Sensing Technology
}

Atanu Kumar Raha ${ }^{1}$, Amitav V. Mishra ${ }^{2}$, Sumita Ghatak ${ }^{3}$, Sumana Bhattacharjee ${ }^{4}$, Srilekha Raha ${ }^{5}$, Souvik Saha ${ }^{6}$, Ranajit Sengupta ${ }^{7}$

1,5,6,7 Techno India University, sector V, Salt Lake, Kolkata, India

${ }^{2}$ Forest Directorate, Aranya Bhawan, Sector III, Salt Lake, Kolkata, India

${ }^{3,4}$ D.F.O, Forest Directorate, W.Bengal, India

\begin{abstract}
West Bengal is one of the most densely populated States of India. The State is predominantly agriculture-based, with only $13.4 \%$ of the total land area being reserved as notified Forest. The Forest ecosystem however is extremely diverse. With the initiation of World Bank aided Social Forestry Project in the State in 198081, an ambitious programme was initiated to bring large chunks of the barren lateritic tracts of the State under green cover. Subsequently, another World Bank aided West Bengal Forestry Project was initiated during 1990s, for improvement of Government-owned degraded forests through people's participation. The present paper shows the usefulness of RS/ GIS technology in real-time assessment of forest/ tree cover, as part of monitoring of afforestation/ social forestry programme, on a large landscape level. A time series analysis of changes of Forest cover will also facilitate formulation of REDD+ Projects in the State.
\end{abstract}

Keywords- Forest Cover in West Bengal, ERDAS software, ARCINFO software, Forest Survey of India, RS, GIS, Joint Forest Management, Monitoring afforestation, Forest cover mapping using Remote Sensing, Tree cover assessment.

\section{INTRODUCTION}

The State of West Bengal extends from the Himalayas in the North to the Bay of Bengal in the South. It lies between $21^{\circ} 34^{\prime} \mathrm{N}$ to $27^{\circ} 13 \mathrm{~N}$ latitude and $85^{\circ} 50$ ' $\mathrm{E}$ to $89^{\circ} 52$ 'E longitude covering a geographical area of 88,752 sq $\mathrm{km}$., which is $2.7 \%$ of the total geographical area of the country. Population density of the state was 767 per sq.km as compared to that of the country at 273 per sq km. (1991 Census). After the promulgation of Estates Acquisition Act of 1953, all the recorded forests of the state other than those under lease agreements with tea gardens had been brought under the management of Forest Department, West Bengal. Subsequently the Tea garden forests had been vested with Forest Department as "Resumed Forests". At present, all the recorded forests of the State are classified as Reserved Forests, Protected Forests and Unclassed State Forests, under the Indian Forest Act, 1927. The recorded forestland of the State (11879 sq km.) is $1.54 \%$ of the recorded forest land of India (770078 sq km.) (State Forest Report, West Bengal, 2010-11).

West Bengal has one of the oldest history of scientific management of its forests which dates back to midnineteenth century. Detail working plans were prepared by the British Foresters for management of this natural resource, which depended heavily on economic aspect of value addition, but did not totally overlook the aspect of Bio-diversity Conservation. In late nineteenth and early twentieth centuries, the art and science of artificial regeneration with fast growing spp. like teak (Tectona grandis), sal (Shorea robusta), champ (Michelia champaca), etc., after clear-felling of natural forest in Northern Bengal, was perfected.

However, in the districts of undivided Midnapore, Bankura and Purulia, the post-independence scenario was different. On the basis of Estate Acquisition Act of 1953, all the zamindari forests in these districts were taken over by the State and their management was vested with State Forest Department. These forests were notified as Protected Forests, under Indian Forest Act of 1927, without clearly defining or settling the rights of forest fringe people. These notified forests were in disjointed patches, varying between a few hectors to a few hundred hectors. The forests were surrounded by villages with large population and high population density. The poverty levels in these villages were also high due to near-absence 
of irrigation facilities and industries, as well as low agricultural productivity as the fields were monsoon-fed. The fringe population depended heavily on the sal coppice forests for their subsistence, fuel wood and fodder requirement. The heavy biotic pressure started denuding the forests and by the beginning of 1970s, most of the sal coppice forests in these districts had degenerated to bushy/scrub forests. The efforts of the Forest Department staff to control the process of degradation, by mere use of force or legal measures, led to total failure. The trend continued till mid seventies.

Meanwhile, in South Bengal, in the districts of Bankura, Midnapore, Purulia and elsewhere, large scale Eucalyptus and Acacia auriculiformis (Akashmoni) plantations were raised during sixties and seventies, as part of "degraded forest regeneration". Sal ( Shorea robusta) plantations were also tried in degraded sal forest areas, however, with limited success due to heavy biotic pressure from fire and grazing in the young plantations. Beautiful patches of Eucalyptus and Akashmoni plantations provided ground cover to all those barren/degraded forest areas, which could not be otherwise regenerated with slow growing, miscellaneous species.

Simultaneously, another socio-economic experiment was initiated in Arabari village of Midnapore district by Forest Department in 1972-73, trying to regenerate nearly 1200 ha of degraded/ blank forest area with the help of around 615 families. The idea of sharing of usufructs with the villagers, from the resuscitated forest areas, was conceived in the Project. The success of the experimental project ultimately led to the generalized concept and adoption of Joint Forest Management (JFM) at the State and National level. The first Govt. Order on sharing of usufructs and constitution of JFM Committees was issued in 1988 and over the next few years, the voluntary movement of forest protection through people's participation spread like wild fire. Nearly 4000 Forest Protection Committees were formed to protect nearly 500,000 Ha of degraded forest areas of the State.

The movement received a material boost with the introduction of World Bank sponsored Social Forestry Project from the beginning of 1980s. The distribution of vested waste land to landless rural families, in the three districts of South West Bengal, in later part of the 1970s/ early ' 80 s was also a giant step towards the future success of farm forestry in South West Bengal (Guhathakurata and Roy, 2000).

Early eighties also saw the global resurgence of Biodiversity conservation and renewed interest in the preservation of the endangered flora and fauna of the world. In keeping with the international and national trend, West Bengal too shifted its priority in forest management towards conservation of natural flora and fauna in the forests and the wetlands. National forest policy of 1988 and the Forest Conservation Act, 1980 put severe restriction on the harvesting of the natural forests. The late eighties and early nineties saw increased activities in wildlife management in West Bengal. Large tracts of forest areas, having ecological importance and significance, had been declared as protected areas in the form of National Parks, Sanctuaries, Biosphere Reserves and Tiger Reserves. Policy decisions were taken to hand over administrative control of these protected areas (PA) to Wildlife Wing for more intensive management from wildlife conservation angle. Till date, nearly $34 \%$ of the total recorded forest areas of the State have been declared as P.A., as compared to $16.5 \%$ for the entire country.

\section{MATERIALS AND METHODS}

\subsection{Geographical location}

The State of West Bengal extends from the Himalayas in the North to the Bay of Bengal in the South. It lies between $21034^{\prime} \mathrm{N}$ to $27013^{\prime} \mathrm{N}$ latitude and $85050^{\prime} \mathrm{E}$ to $89052^{\prime} \mathrm{E}$ longitude covering a geographical area of 88,752 sq $\mathrm{km}$.

\subsection{Objective of Research}

The main objective of this case study is to develop a methodology, based on Remote Sensing technology, for rapid and near real-time monitoring of forest and tree cover for the entire state of West Bengal, in order to evaluate the success/failure of joint forest management and social forestry programme.

2.3 Identification of problems leading to the research

The Government forests in the State had been subjected to severe biotic pressure from the forest fringe population who depend on the forest for their livelihood and sustenance. At the same time, there were large chunks of Government owned waste land whose ownership were distributed to the land less/agricultural labourers as part of land reform measures. With the initiation of World Bank aided projects on social forestry and Joint Forest Management (JFM), for resuscitation of degraded forest land through people's participation, large scale afforestation programmes had been initiated in the State from the 1980's. The degraded forest also started recuperating through JFM. However, the conventional method of monitoring the afforestation programme as well as status of forest/tree cover is fraught with many loop holes. These are (i) time consuming, (ii) dependent on integrity of data collection at field level and (iii) sometimes outdated due to lag in data collection period and compilation of the same, as result the management at the policy level are unable to monitor and correct the course of deviation, if there is any, concurrently with the 
implementation of the project.

Forest Survey of India had started evaluating the forest cover of the country, based on LANDSAT imagery and through visual interpretation of the satellite data from 1987. Such rapid appraisal of forest cover, on national basis, led to discrepancies in results on vegetative cover in the States. In order to find the actual status of forest cover of the State, prior to launching of Social Forestry project and initiation of Joint Forest Management (JFM) with people's participation in the in the early 80 's, and to monitor the changes over the years, West Bengal Forest Department took up collaborative project on Forest vegetation mapping, using satellite imagery, with RRSSC, Kharagpur, Department of Space, Govt. of India. Forest cover mapping was done with December, 1988 data from IRS-1A satellite, using supervised classification, and it showed that total forest and vegetation cover in the state had gone up to $14.32 \%$ from the recorded forest area of $13.4 \%$ as in 1988 (Sudhakar et al., 1992). Subsequent, periodic change detection studies have been carried out with November/December, 1991data from IRS-1A/ 1B, November/December, 1994 data from IRS-1B (Sudhakar et al., 1996) \& 1997 Nov/Dec data from IRS-1C through the infrastructure of RRSSC, Kharagpur, Dept. of Space, Govt. of India. The Remote Sensing / GIS Cell of West Bengal Forest Dept., was launched in late 1999. January, 2000 data from IRS 1D and March, 2004 from IRS-P6 satellites were processed by the GIS Cell of the Forest Department. The time-series output had shown a considerable improvement in the forest cover of the state up to the year 2006 (Raha, 2007).

At the initial stage of the Project, the district maps with latitude/longitude information were registered, Georeferenced and digitized with Polyconic Projection, Datum Modified Everest. Other important features like Roads, Railways, Rivers etc., were digitized as separate layers. The central meridian and Projection origin were fixed at $88^{\circ} \mathrm{E}$ and $24^{\circ} \mathrm{N}$. The radiometrically corrected Digital Data on CD-ROM, obtained from NRSC, Hyderabad, were imported into image format using ERDAS Imagine software. The imported scenes were then registered and geo-referenced with respect to the known features of the digitized coverage. Satellite Imageries were then extracted for each district, as thematic land use maps. Basic and available standard information like population, area, forest composition, FPC details of Forest Protection Committees (FPC) etc., were then attached to the digitized coverage as GIS data base.

Indian Remote Sensing Satellite, IRS-P6 was launched in October, 2003. The Mission's main objective was to provide continued satellite remote sensing data services for integrated land and water resources management, at micro level, with enhanced multi-spectral and spatial coverage.

The IRS-P6 satellite, weighing around $1250 \mathrm{~kg}$ had been launched from Sriharikota by the indigenously built Polar Satellite Launch Vehicle (PSLV), at an altitude of around $800 \mathrm{~km}$. The Satellite is carrying three sensors, the LISSIII and LISS-IV multi-spectral sensors and the AWiFS. Resolution of LISS III in visible, NIR and SWIR bands is $23 \mathrm{~m}$, that of LISS IV in visible and NIR bands is $5.8 \mathrm{~m}$ and AwiFS has a resolution of $56 \mathrm{~m}$ in visible, NIR and SWIR bands.

For the purpose of Forest and Tree cover monitoring in the State as in 2010, the GIS Cell of West Bengal Forest Directorate had requisitioned from NRSC, Hyderabad one Scene (Row 55, Path 107) of AWiFS data for December 2010 for change detection study. Since AWiFS data has a very large swath of $700 \mathrm{~km}$, the entire geographical area of West Bengal was covered by the single scene. However, the AWiFS data was found very useful for rapid appraisal of Forest and Vegetation status of the State.

The Digital data were then registered with Georeferenced vector coverage data, containing State and district boundaries of West Bengal, using ARC INFO GIS software.The next step was to carry out unsupervised classification using ERDAS Imagine Image Processing software. The algorithm adopted was "Initializing the Means" along Diagonal Axis, Standard Deviation 2 and Convergence threshold of 0.980 . Number of classes was fixed between 20 to 30 , depending on the extent and diversity of forests in the districts. Attributes of the classified images were then grouped into different classes like Forest Cover, Vegetation / Tree cover / woodlot, water bodies and agriculture based on field knowledge, ground truth verification and earlier reference maps (Yichun et al., 2008).

The same procedure, as was followed in case of forest mapping with 2010 data, were followed while generating state of forest cover as in 2014. The AWiFS data pertained to Dec/ January period from the latest Indian Remote Sensing Satellite Resourcesat 2, launched in April 2011. Geometrically and Radiometrically Multispectral, 3 band digital data ( Band 2: 0.62-0.68 $\mu \mathrm{m}$, Band 3: 0.77-0.86 $\mu \mathrm{m}$, Band 4: 1.55-1.70 $\mu \mathrm{m}$ ) with Resolution of $56 \mathrm{~m}$ were procured from NRSC, Hyderabad. These digital images were again georeferenced with respect to 2010 registered images; subsets of districts were generated and unsupervised classification was carried out for 25 classes. The algorithm included Initializing Means along Diagonal Axis, Standard deviation of 2, and Convergence Threshold was kept at 0.980 . 
While doing classification, subset images of the notified Forest areas were specially created for the forest-rich districts of South 24 Parganas and Jalpaiguri in order to segregate forest cover from the tree cover as correctly as possible (Figs. 5-6). In case of Jalpaiguri district, the Tea Gardens with their shed trees created almost a forest-like coverage and these T.G are also interspersed with notified Forest land. Hence, the Tea Gardens were also included in the Forest cover of Jalpaiguri district.However, in case of West Midnapore, Purulia, Bankura, Burdwan and birbhum districts, the recorded forest land is interspersed with vested and private wasteland, containing large scale plantations of Eucalyptus/ Acacia auriculiformis. Such group farm forestry plots have almost similar DN values as in case of plantations of Eucalyptus and Acacia on Forest land, and for the purpose of rapid tree cover monitoring, it was not considered worthwhile to delineate small forest patches for segregation of forest cover from forest-like non-forest tree cover. The consolidated patches of Eucalyptus/Akashmoni (Acacia auriculiformis) and Casuarina (Casuarina equisetifolia) plantations, raised on private/vested wastelands under Social/Farm Forestry programmes, also have forest-like microecosystem and that is why, these tree cover have been enumerated as Forest cover though these may be located outside recorded Govt. Forest and may be part of Group Farm Forestry.

Moreover, North and South Dinajpur, Malda, Nadia, Murshidabad, Coochbehar, Howrah and Hooghly districts contained very small percentage of recorded Forest land (Fig. 5), which could not be delineated for the purpose of segregation. However, Malda, Murshidabad and Nadia districts contained extensive and intensive cultivation of fruit trees and orchards like Mango, litchi etc which created a plantation forest like ecosystem in these districts. Similarly, the districts like South and North 24 Parganas, minus the Mangrove Forest, contain extremely rich village woodlots and cocoanut plantations, which also have the effect of forest-like ecosystem with regard to micro-climate and soil-moisture regime. Standard False Colour Composites for these districts were classified using the same algorithm, for generation of tree/vegetation cover and these were shown as forest cover for the purpose of computation of forest cover for the State.

The same protocol for forest cover classification, as were followed in previous years, was adopted for the latest classification of Mangrove Forest cover as in 2014. The permanent water bodies like rivers and creeks in Sundarban mangrove forest was included as Mangrove Forest cover while computing the Forest cover of the districts of South and North 24 Parganas. The rationale behind this is that historically, all such water bodies enclosed within recorded Forest boundaries, were also recorded and quoted in the past as forest land. These wetlands are integral part of the mangrove ecosystem and should not be construed as degraded forest or water bodies, which can be planted up to increase the forest cover. This protocol has been adopted by West Bengal Forest Department to ensure a uniform platform for comparison of forest cover with the past records and to facilitate change detection. Forest Survey of India, Dehradun, in their study, had left out almost $50 \%$ of mangrove forest (water bodies) while computing the Forest cover of the State.

Darjeeling district has large percentage of geographical areas under Tea Gardens, with shade trees, and the tea gardens have also been included as forest cover for the 2014 classification protocol.

This new protocol of 2014 classification, which was not followed in the previous years' assessments, made the State's forest cover increase by an appreciable percentage. This change in protocol was adopted to keep parity with the forest cover classification done by the Forest Survey of India on a country basis.

\section{RESULTS AND DISCUSSION}

The Forest cover, as calculated on the basis of December 2014 (Table 2, Fig. 7), AWiFS satellite data, comes to $15.10 \%$ of total geographical area of the State, as compared to the figure of $15.10 \%$ in the year 2010 and the figure of $15.68 \%$ in the year 2006. Forest Survey of India, in its India State Forest Report 1989 had arrived at the State's Forest Cover figure at 9.03\%. India SFR 2005, published by FSI had calculated the percentage of Forest cover of the state at $13.99 \%$, whereas the 2011 Report of FSI finally arrived at the State's Forest cover figure of 14.64\% (India State of Forest Report, 1989, 2005, 2011). However, in its State Forest Report, 2013, FSI arrived at the forest cover figure of $18.93 \%$ in case of W.Bengal. Even though the classification algorithm and protocol followed by the Central and State agency are different, yet both the assessments show that the State has around $18 \%$ of its geographical area under Forest cover. One very obvious discrepancy is the interpretation of Mangrove forest as Forest cover. As already have been explained in earlier paragraph, Sundarban has nearly 4200 sq km. of Reserved Forest, which comprises nearly 2200 sq $\mathrm{km}$. of land mangrove vegetation and $1800 \mathrm{sq} \mathrm{km}$. of water body which is an integral part of mangrove/ estuarine forest. Protocols followed in the classification by FSI and State Forest Department may be the basis of future reconciliation.

Though the forest cover in the State, as assessed till 2011 by FSI, Govt of India and W.B. Forest Department independently, had appreciable variations, yet the 2013/ 
2014 assessment by both the agencies have arrived at almost similar figures of forest cover percentage.

The positive changes in Forest cover, as in the present study, are due to difference of data quality, classification protocol, as well as the regeneration of planted and harvested forest (as per approved Working Plan). Group Farm Forestry and extensive fruit orchards have created the ambience of forest cover in those districts which are otherwise devoid of notified forest land. Similarly, in Darjeeling and Jalpaiguri districts, extensive Tea Gardens with shade trees probide excellent cover against soil erosion as well as, habitat of wild animals like leopards. The latest assessment of Forest cover, as in 2014, shows that there has not been any degradation or reduction of Forest cover in the State even after the closure of the World Bank aided Joint Forest Management Project in W.Bengal which had stopped funding almost a decade back. The benefits that accrued to the forest fringe communities, due to regeneration of degraded forest and vacant wasteland, has resulted into institutionalization of the practice of participatory forest management. Though W.Bengal has the highest population density in the country, yet the culture of tree cultivation and forest conservation has been firmly embedded in the ethos of the people in the rural as well as urban areas. When global warming due to deforestation and degradation have been posing a serious threat to the developed and developing countries alike, W.Bengal's pioneering performance will show the importance of people's involvement in reducing emission of Green House Gases through deforestation and degradation.

Moreover, the uniqueness of this study is that this is the first time a more detailed analysis of the satellite imageries (Figs. 1-4) could be done to calculate the total tree/ vegetation cover of the State, district-wise, which can form the basis of assessment of Forest/ Tree Carbon pool in the State, as well as preparedness of the State towards implementation of REDD+ Projects under Climate Change scenario. The forest-cum-tree cover is estimated at around $19 \%$, against the notified forest land of $13.4 \%$ which shows that the only prospect of increasing the forest cover in the State, to reach a national target of $33 \%$, lies in implementation of large scale Social Forestry programme, since in a densely populated state like West Bengal, there is no scope of increasing the quantum of recorded forest land any further.

Forest cover data of West Bengal as in 2014

\begin{tabular}{|c|c|c|c|c|c|c|c|}
\hline & & \multicolumn{6}{|c|}{$\left(\right.$ Area in $\mathrm{Km}^{2}$ ) } \\
\hline District & $\begin{array}{c}\text { Recorded } \\
\text { geographical area }\end{array}$ & $\begin{array}{l}\text { Recorded } \\
\text { forest area }\end{array}$ & $\begin{array}{l}\text { Forest } \\
\text { cover } \\
2010\end{array}$ & $\begin{array}{c}\text { \% forest } \\
\text { cover } \\
2010\end{array}$ & $\begin{array}{c}\text { Digitised } \\
\text { geographical } \\
\text { area } 2014\end{array}$ & $\begin{array}{c}\text { Forest } \\
\text { cover } 2014\end{array}$ & $\begin{array}{c}\% \\
\text { forest } \\
\text { cover } \\
2014 \\
\end{array}$ \\
\hline 24 Pgs. (S) & 10159 & 4220 & 3758 & 36.56 & 10279 & 3732 & 36.31 \\
\hline 24 Pgs. (N) & 3977 & 43 & 39 & 0.95 & 4087 & 447 & 10.94 \\
\hline $\begin{array}{c}\text { Midnapore } E \\
\& W \\
\end{array}$ & 14081 & 1709 & 2269 & 16.27 & 13949 & 2294 & 16.45 \\
\hline Purulia & 6259 & 876 & 876 & 13.81 & 6343 & 1247 & 19.66 \\
\hline Bankura & 6882 & 1482 & 2146 & 31.16 & 6888 & 2000 & 29.04 \\
\hline Burdwan & 7024 & 277 & 909 & 12.89 & 7051 & 833 & 11.81 \\
\hline Birbhum & 4545 & 159 & 355 & 7.77 & 4571 & 337 & 7.37 \\
\hline Jalpaiguri & 6227 & 1790 & 1852 & 29.64 & 6249 & 2056 & 32.90 \\
\hline Darjeeling & 3149 & 1204 & 1101 & 34.84 & 3160 & 2074 & 65.63 \\
\hline Cooch Behar & 3387 & 57 & 98 & 2.85 & 3339 & 142 & 4.25 \\
\hline Howrah & 1467 & 0 & 0 & 0 & 1499 & 236 & 15.74 \\
\hline Hooghly & 3149 & 3 & 3 & 0.09 & 3167 & 100 & 3.16 \\
\hline N. Dinajpur & 3140 & 18 & 18 & 0.57 & 3167 & 89 & 2.81 \\
\hline S. Dinajpur & 2219 & 0 & 0 & 0 & 2130 & 38 & 1.78 \\
\hline Malda & 3733 & 20 & 20 & 0.55 & 3527 & 314 & 8.90 \\
\hline Nadia & 3927 & 13 & 13 & 0.34 & 3840 & 220 & 5.73 \\
\hline
\end{tabular}


ISSN: 2456-1878

\begin{tabular}{|c|c|c|c|c|c|c|c|}
\hline Murshidabad & 5324 & 8 & 8 & 0.15 & 5358 & 565 & 10.54 \\
\hline Kolkata & 104 & 0 & 0 & 0 & 104 & 0 & 0.00 \\
\hline Total & $\mathbf{8 8 7 5 3}$ & 11879 & $\mathbf{1 3 4 6 5}$ & $\mathbf{1 5 . 1 0}$ & $\mathbf{8 8 7 0 8}$ & $\mathbf{1 6 7 2 4}$ & $\mathbf{1 8 . 8 5}$ \\
\hline
\end{tabular}

Table 2: Comparative statement of Forest Cover, as monitored through GIS/RS cell of W.Bengal, is given below (2010 and 2014 Forest cover assessed by Env \& Forest Sc Department, Techno India University):

\begin{tabular}{|c|c|c|}
\hline Survey Period & \% of Recorded Forest Land & \% Forest cover \\
\hline 1988 & 13.4 & 14.32 \\
\hline 1991 & 13.4 & 14.97 \\
\hline 1994 & 13.4 & 15.06 \\
\hline 1997 & 13.4 & 15.16 \\
\hline 2000 & 13.4 & 15.30 \\
\hline 2004 & 13.4 & 15.52 \\
\hline 2006 & 13.4 & 15.68 \\
\hline 2010 & 13.4 & 15.10 \\
\hline 2014 & 13.4 & 18.85 \\
\hline
\end{tabular}

Table 3: Assessment of Forest cover by Forest Survey of India, Govt of India

\begin{tabular}{|c|c|c|}
\hline State of Forest Report & Data period & Forest cover \% \\
\hline 1989 & $1985-87$ & 9.6 \\
\hline 1991 & $1987-89$ & 9.0 \\
\hline 1997 & 1993 & 9.4 \\
\hline 1999 & $1995-96$ & 9.42 \\
\hline 2001 & 2000 & 12.05 \\
\hline 2003 & 2002 & 13.91 \\
\hline 2005 & 2004 & 13.99 \\
\hline 2009 & 2006 & 14.64 \\
\hline 2011 & 2009 & 14.65 \\
\hline 2013 & $2011-12$ & 18.93 \\
\hline
\end{tabular}

Table 4

\begin{tabular}{|l|l|l|}
\hline $\begin{array}{l}\text { Assessment } \\
\text { Period }\end{array}$ & $\begin{array}{l}\text { Forest cover } \\
\text { assessed by } \\
\text { WB Forest } \\
\text { Deptt (\%) }\end{array}$ & $\begin{array}{l}\text { Forest cover } \\
\text { assessed by } \\
\text { FSI (\%) }\end{array}$ \\
\hline & 14.32 & 9.6 \\
\hline $1988-89$ & 14.97 & 9.0 \\
\hline 1991 & 15.06 & 9.4 \\
\hline 1994 & 15.16 & 12.05 \\
\hline 1997 & 15.3 & \\
\hline $2000-01$ & &
\end{tabular}




\begin{tabular}{|l|r|r|}
\hline $2003-04$ & 15.52 & 13.91 \\
\hline $2005-06$ & 15.68 & 13.99 \\
\hline $2009-10$ & 15.1 & 14.64 \\
\hline $2013-14$ & 18.85 & 18.93 \\
\hline
\end{tabular}

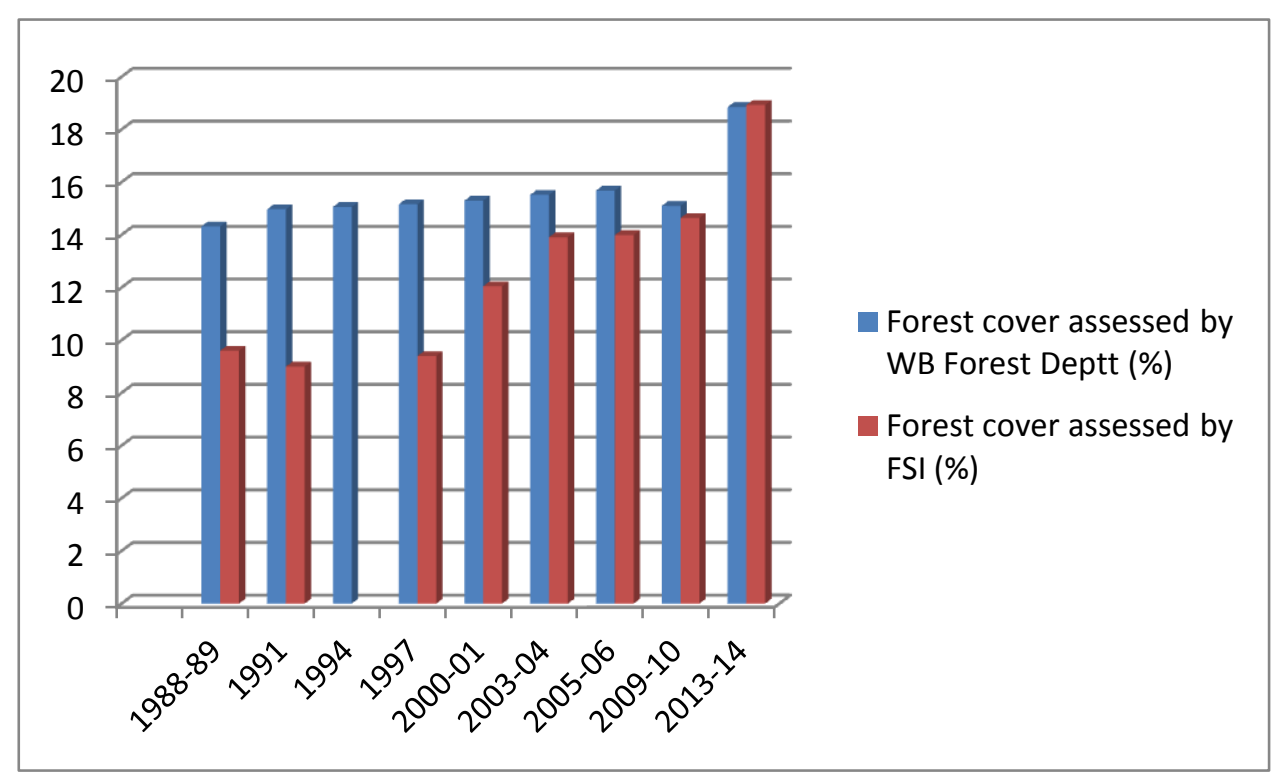

Chart 1: Comparative periodic assessment of Forest cover by WBFD and FSI

Figures: Standard and classified Imageries of a few forest-rich districts

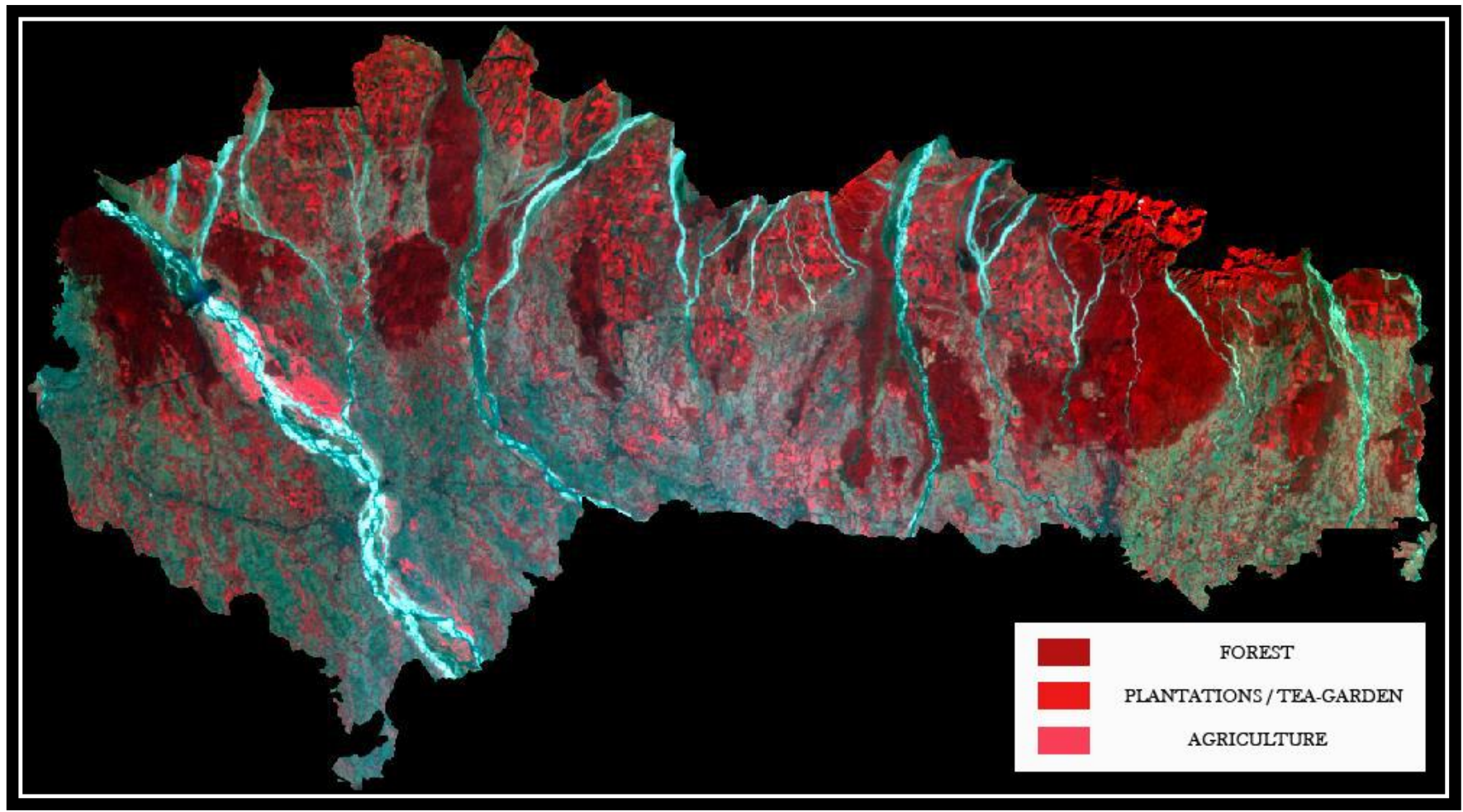

Fig.1: Standard FCC (False Colour Composite) Imagery of Jalpaiguri district, Image period December 2014. 


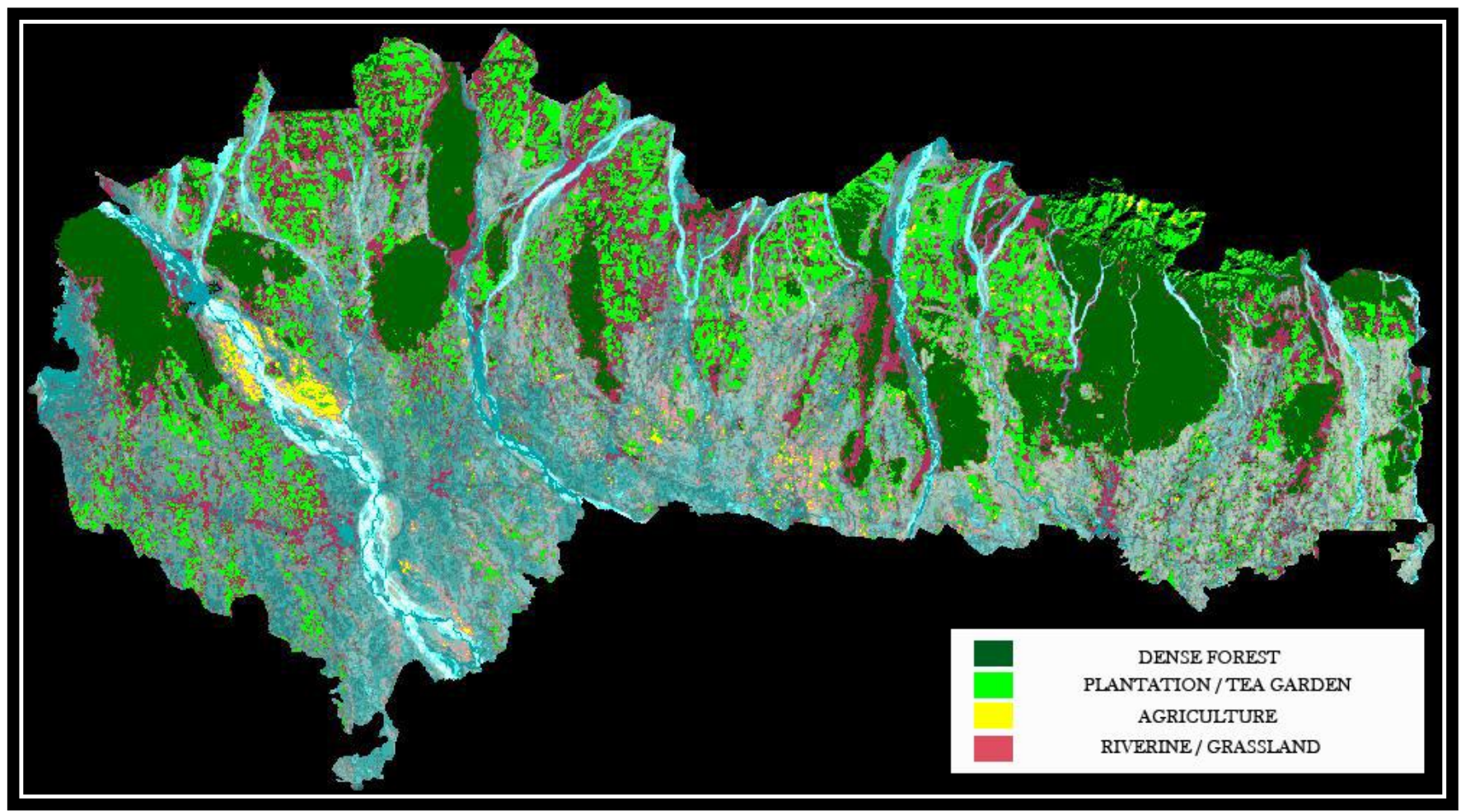

Fig.2: Classified Imagery of Jalpaiguri district, Image period December 2014.

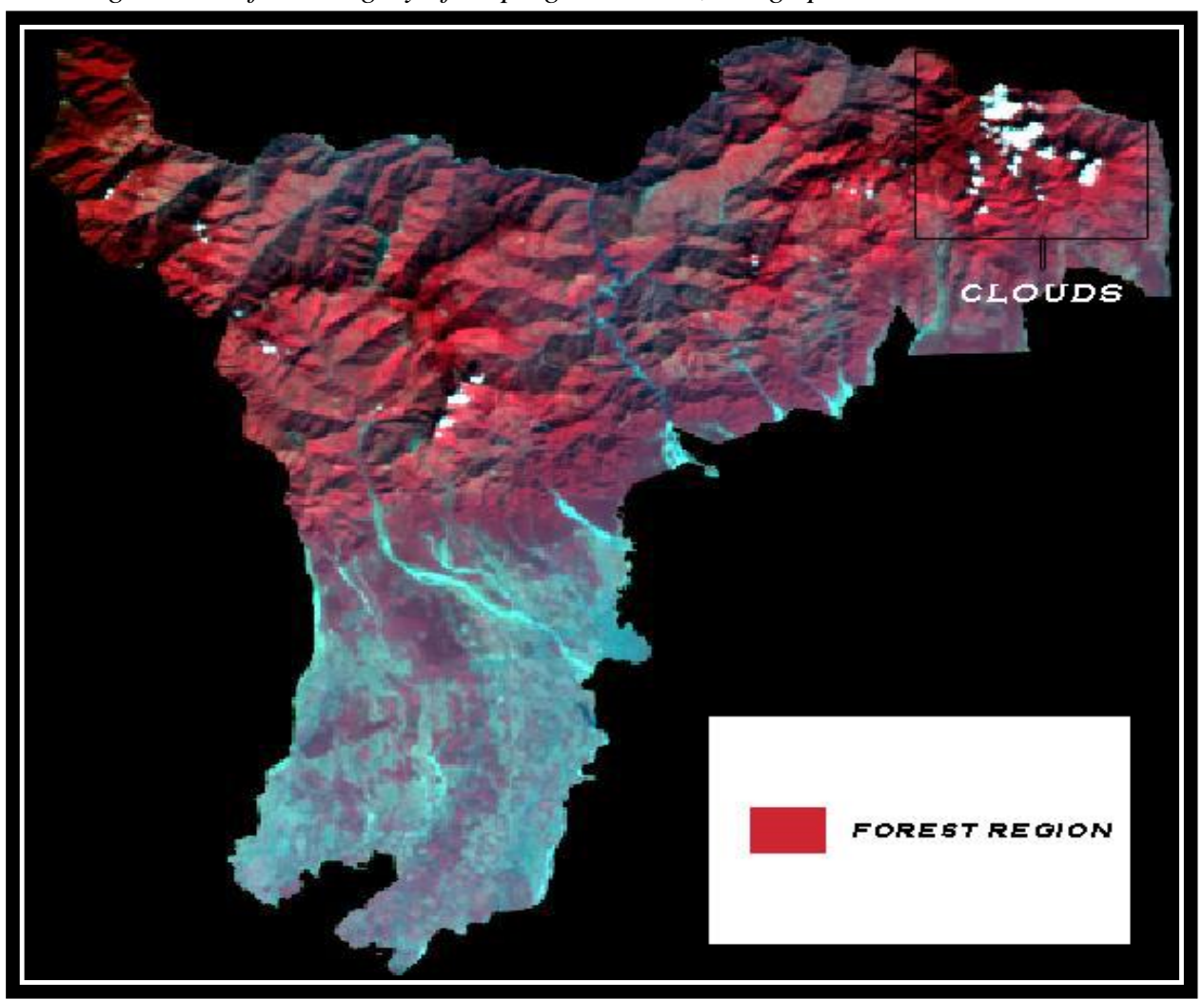

Fig.3: Standard FCC (False Colour Composite) Imagery of Darjeeling district, Image period December 2014. 


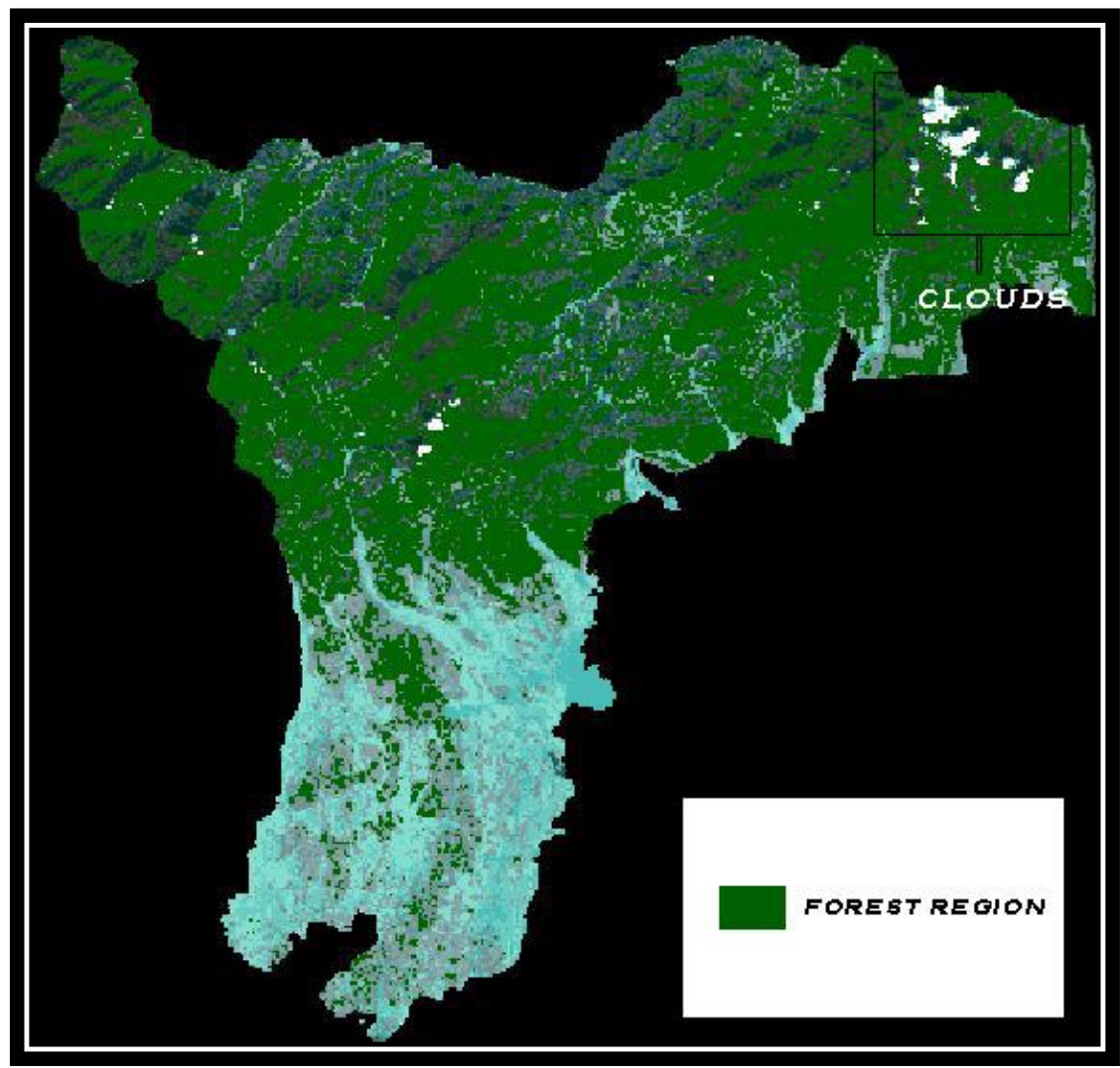

Fig.4: Classified Imagery of Darjeeling district, Image period December 2014.

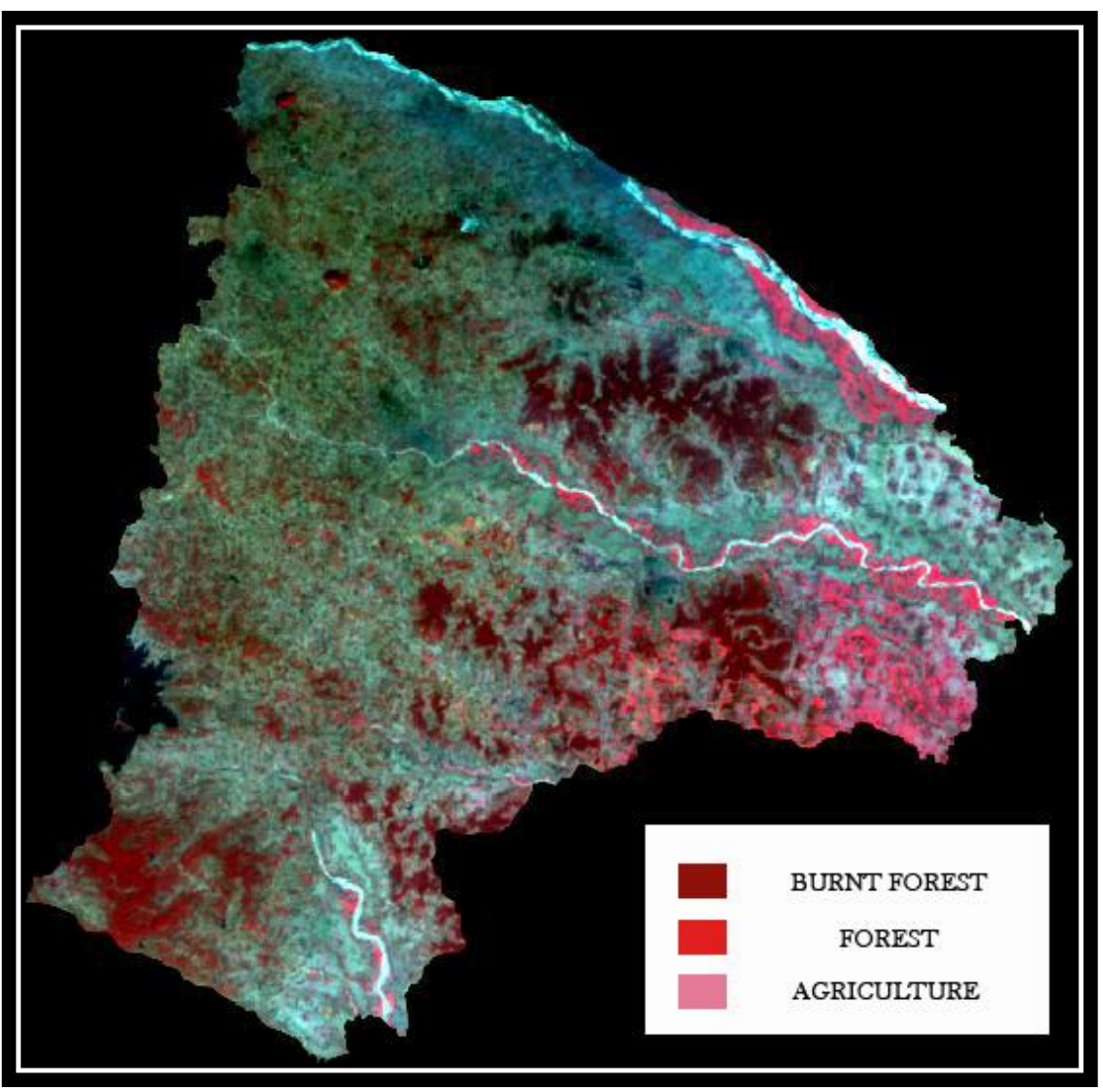

Fig. 5: Standard FCC (False Colour Composite) Imagery of Bankura district, Image period December 2014. 


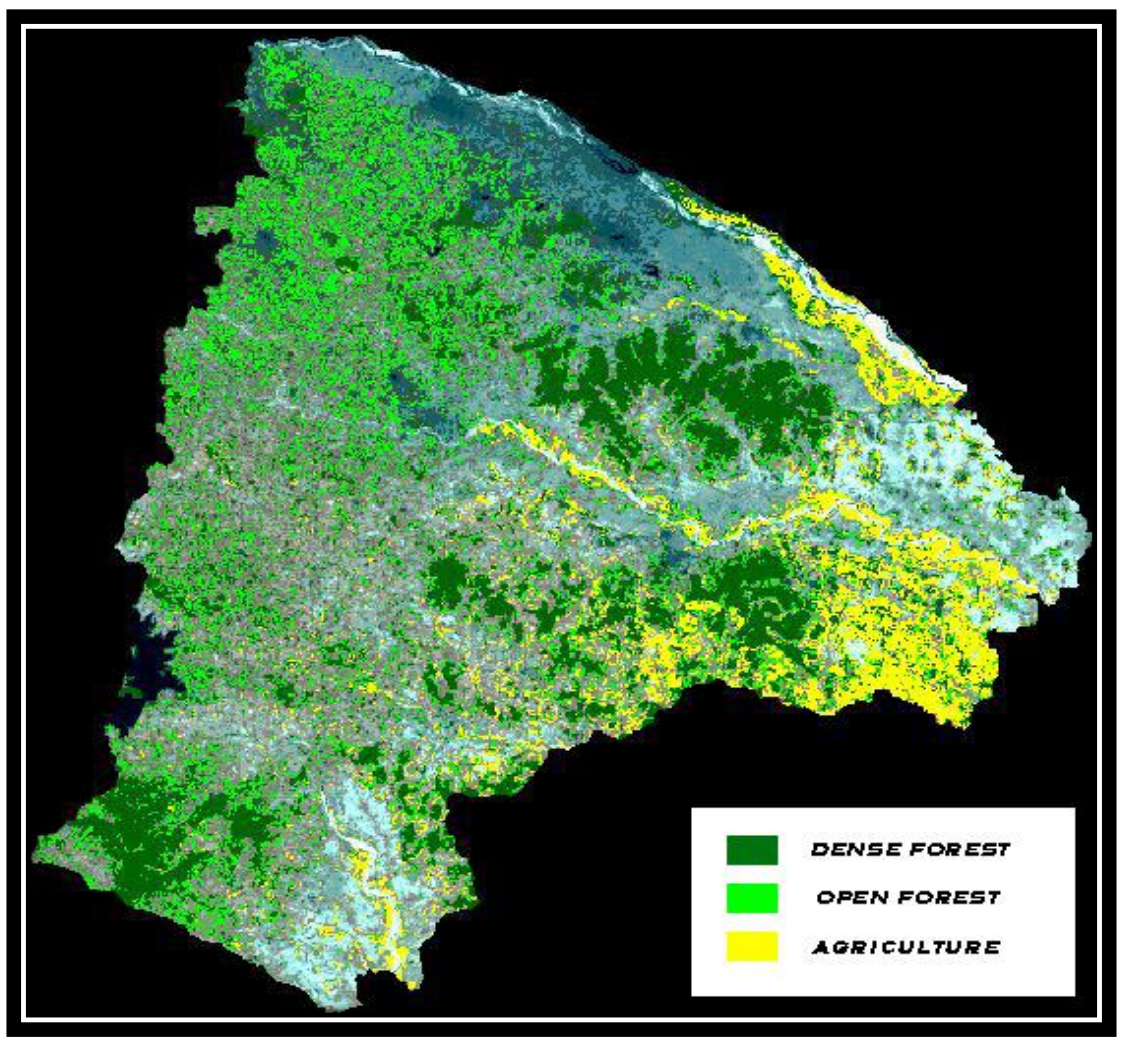

Fig.6: Classified Imagery of Bankura district, Image period December 2014.

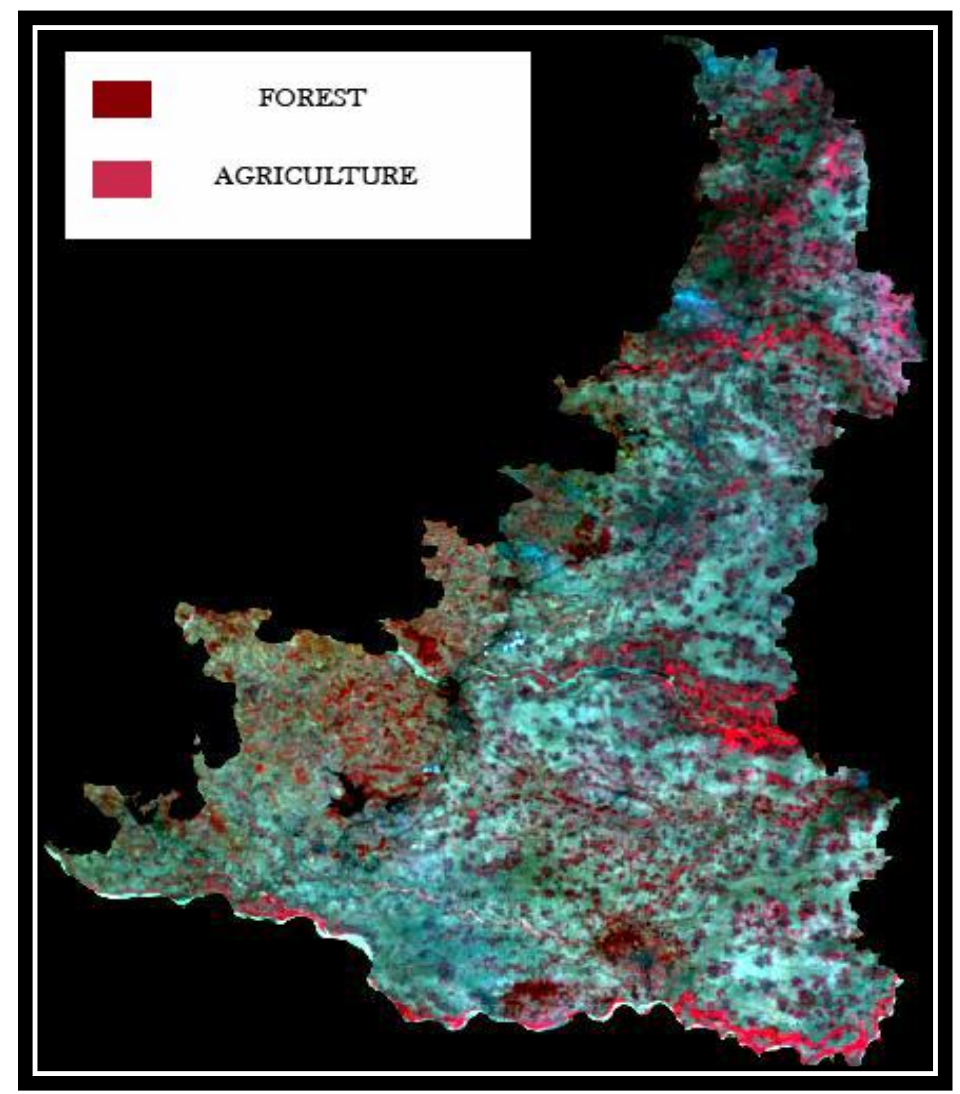

Fig.7: Standard FCC (False Colour Composite) Imagery of Birbhum district, Image period December 2014. 


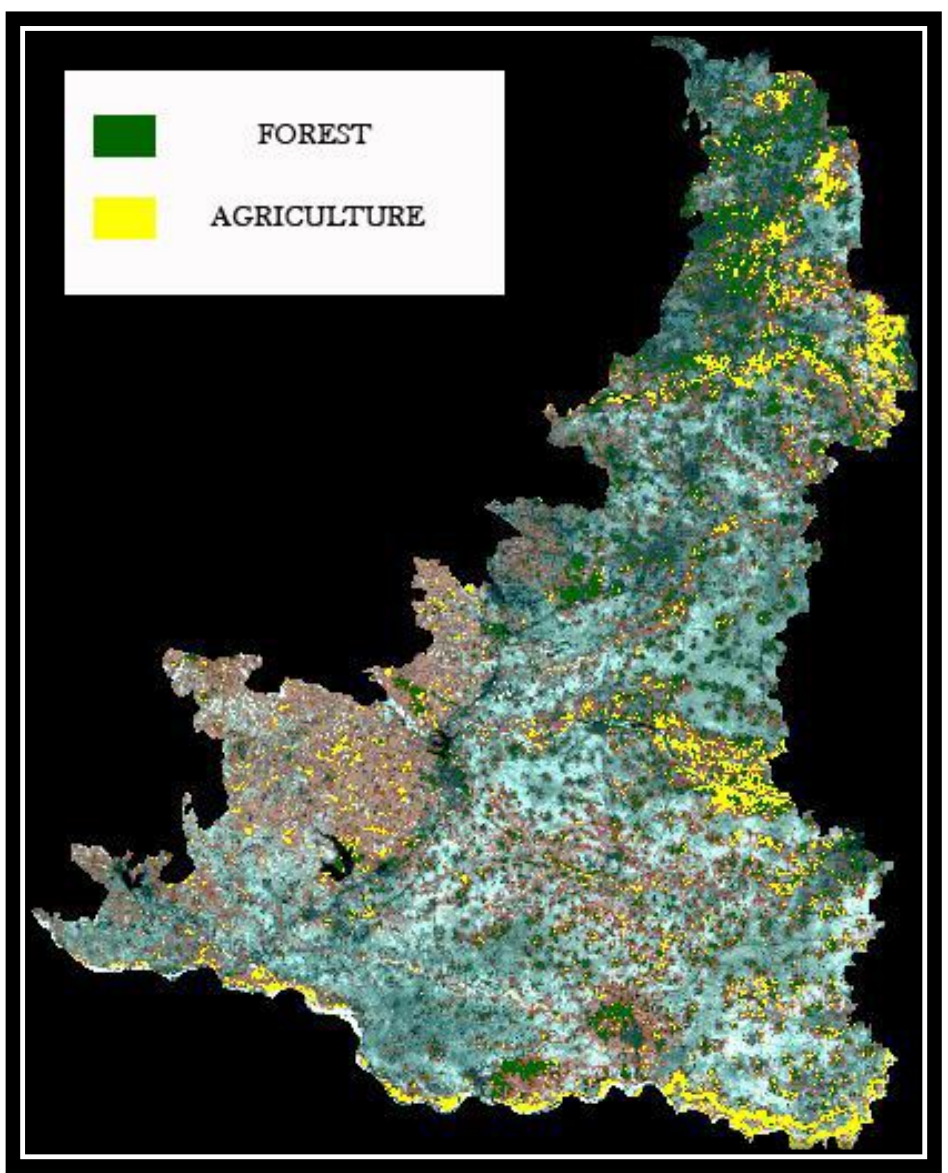

Fig.8: Classified Imagery of Birbhum district, Image periodDecember 2014.

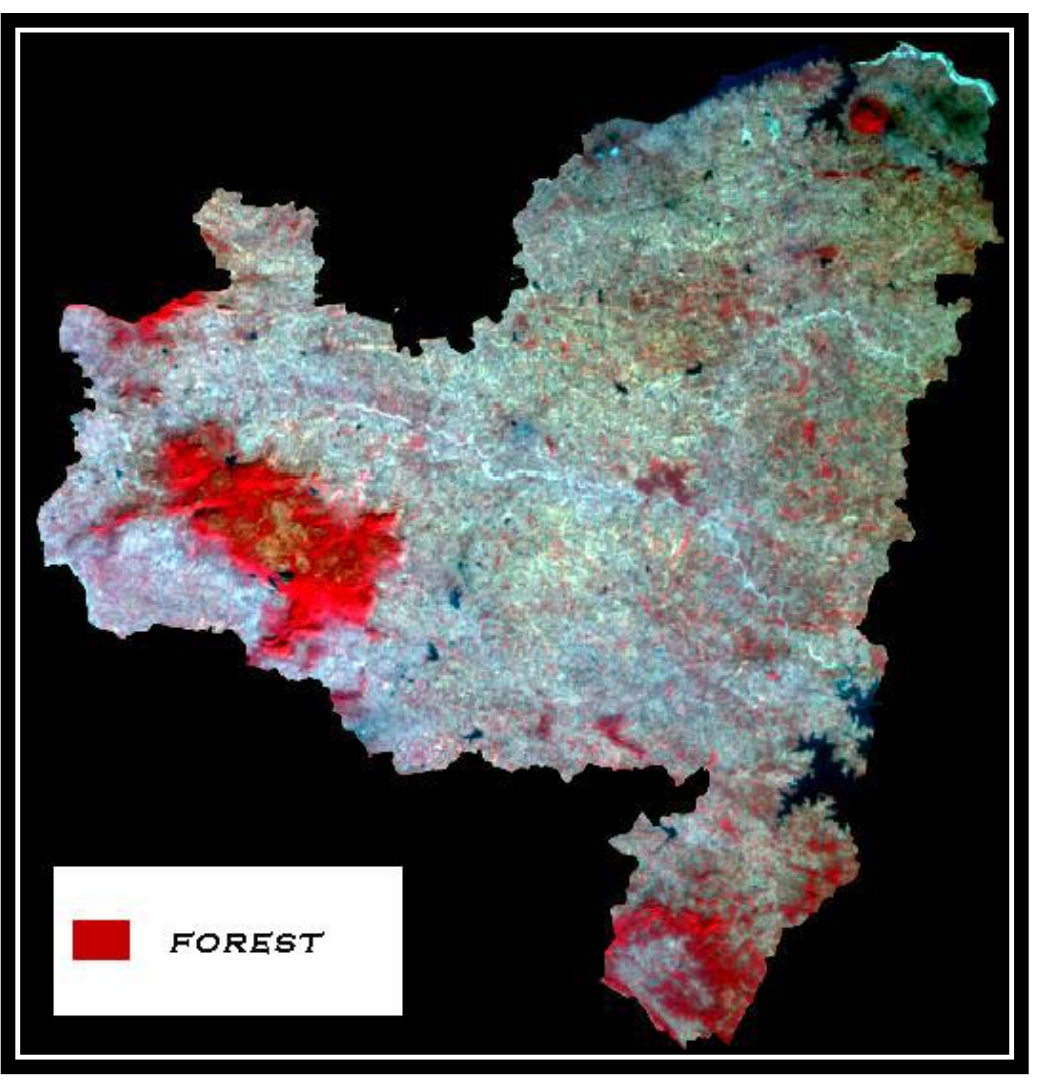


Fig.9: Standard FCC (False Colour Composite) Imagery of Purulia district, Image period December 2014.

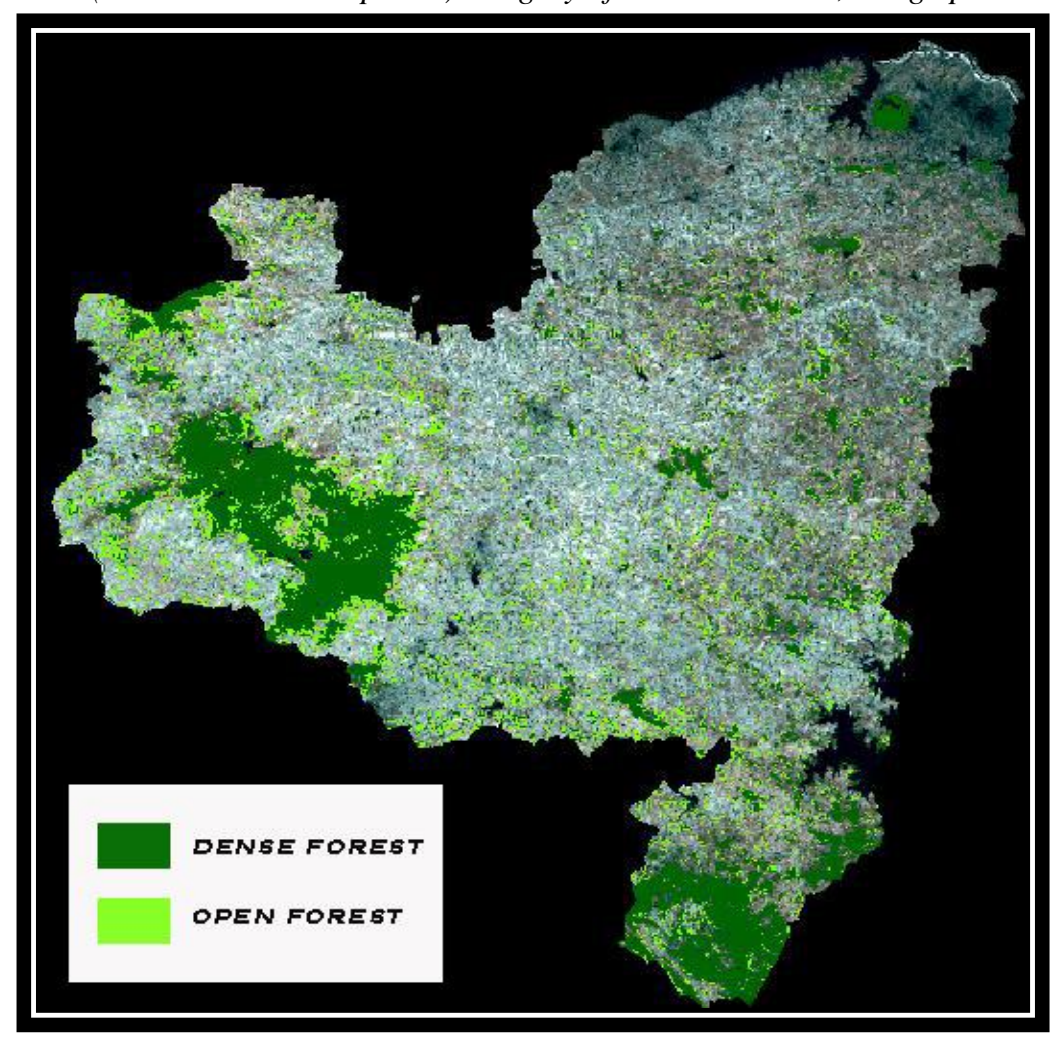

Fig.10: Classified Imagery of Purulia district, Image periodDecember 2014.

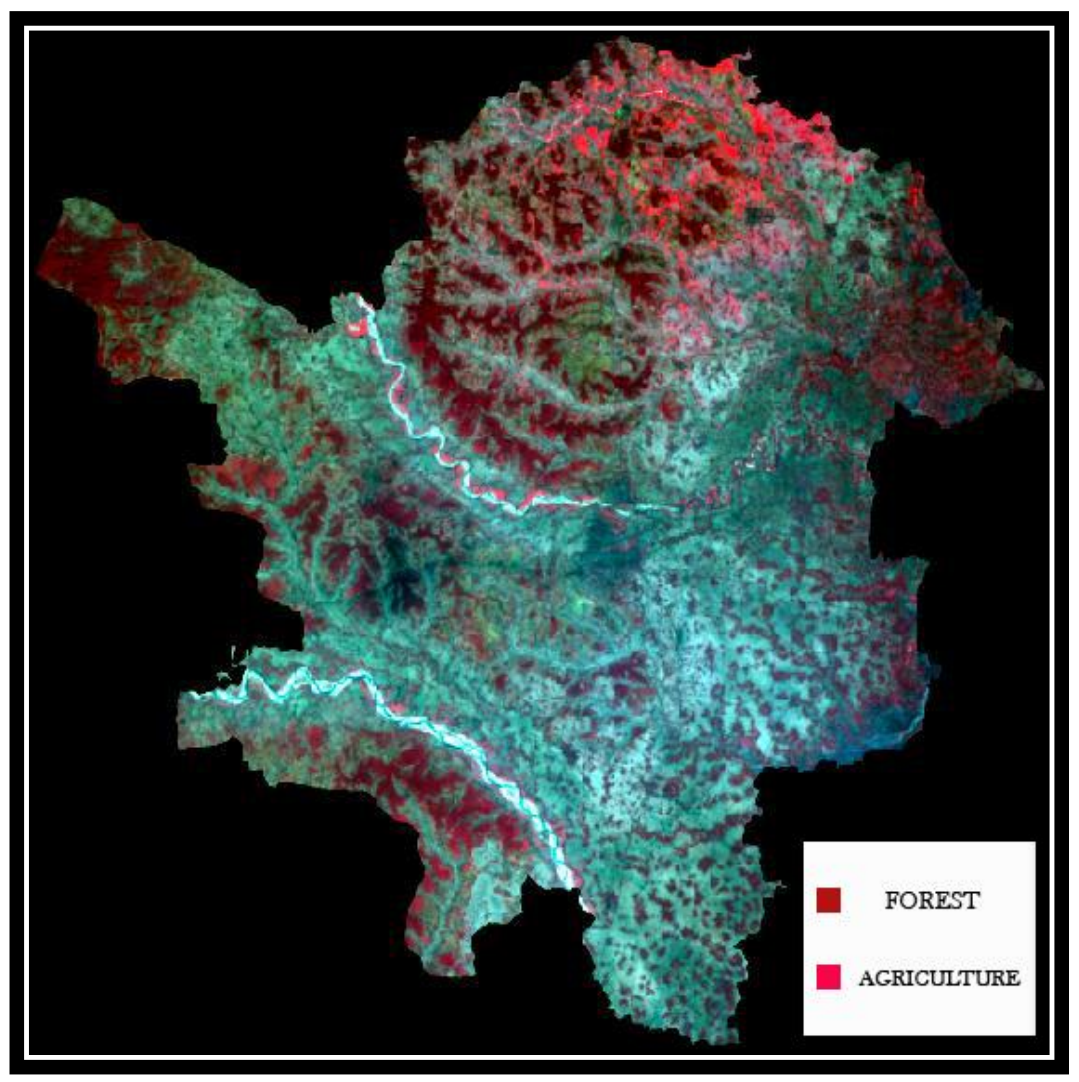

Fig. 11: Standard FCC (False Colour Composite) Imagery of West Midnapore district, Image period December 2014. 


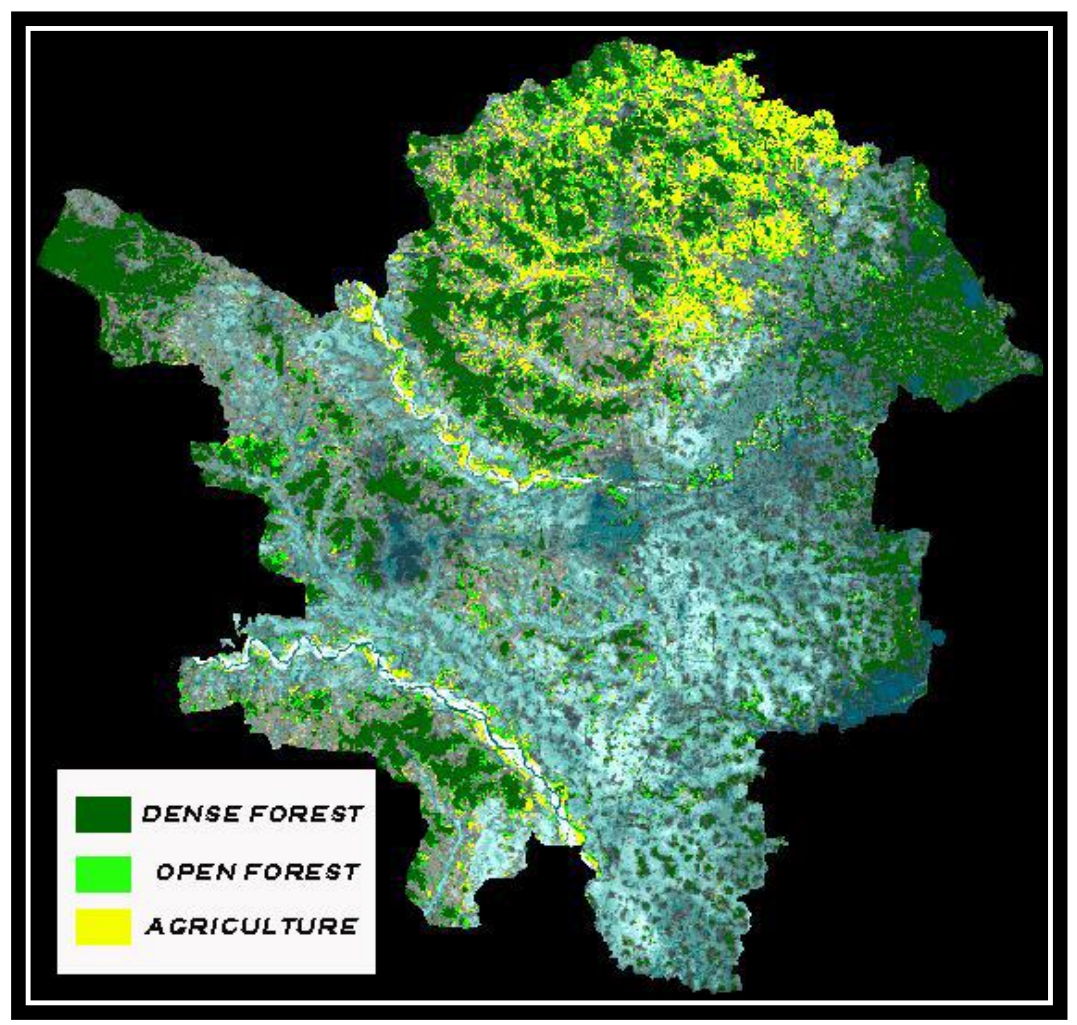

Fig. 12: Classified Imagery of West Midnapore district, Image periodDecember 2014.

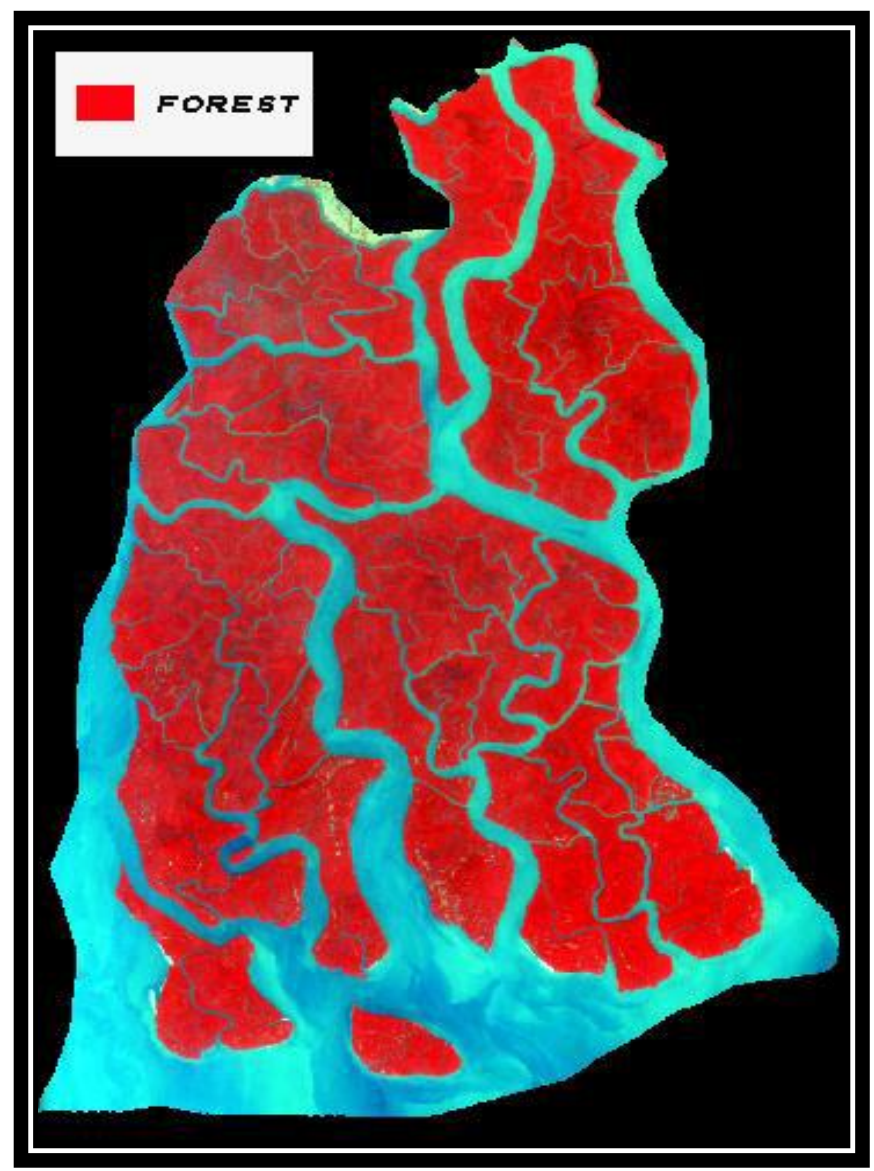

Fig.13: Standard FCC (False Colour Composite) Imagery of Sundarban Tiger Reserve, a part of South 24pgs district. Image 
period December 2014.

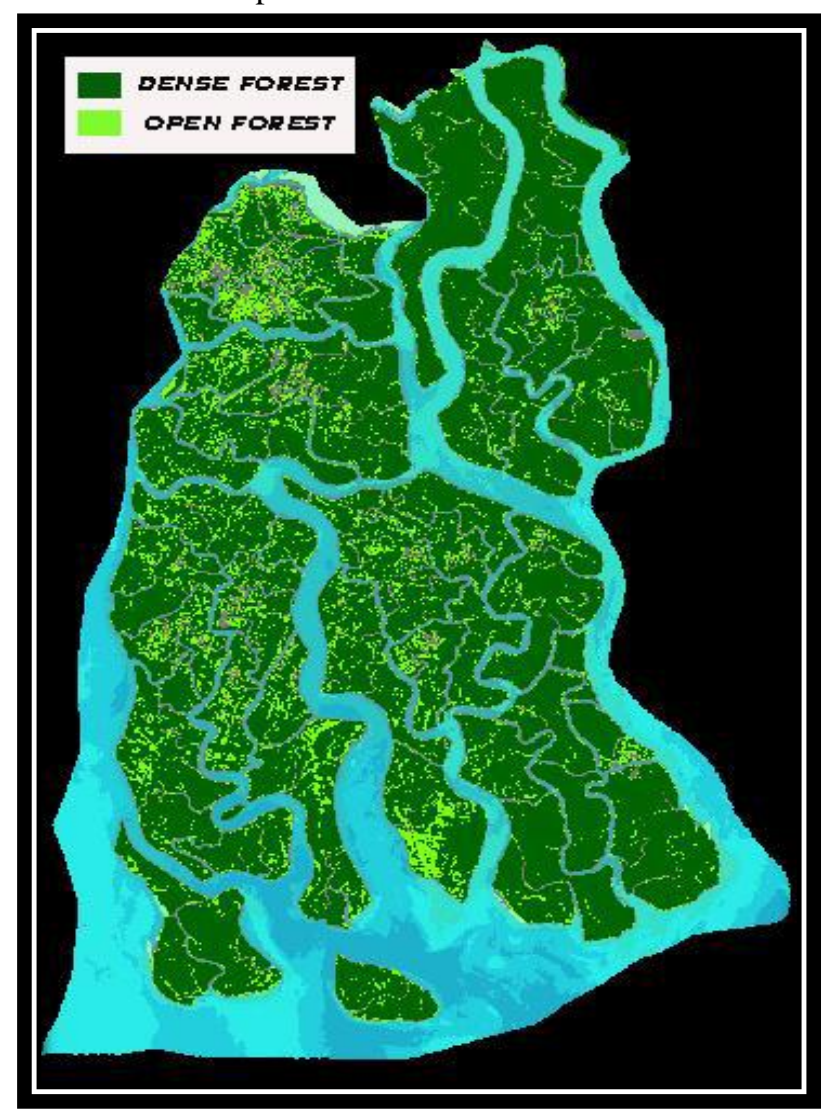

Fig.14: Classified Imagery of Sundarban Tiger Reserve, a part of South 24pgs district. Image period December 2014.

\section{CONCLUSION}

The present study establishes that active participation of forest fringe population have institutionalized the participatory forest management in the State. Time series analysis of the forest and tree cover of the State shows that the status of forest cover has improved irreversibly inspite of discontinuation of supporting inputs like rural development activities. Such methodology can be extremely useful for monitoring of forest and tree cover, especially in the developing countries, and for formulating REDD+ projects as part of carbon sequestration strategy.

The methodology followed in this research paper is based on satellite data which incorporates transparency in the output of monitoring process and has much more reliability as compared to the conventional monitoring. The monitoring data generated is also near real-time one which facilitates the project related decision making process at the highest level. The case study also proves that the technology is not too complicated and can be easily adopted by any Government Organization with reasonable amount of training of a few staff/officers.

The present study also shows the strength and effectiveness of the modern tool of Remote Sensing/GIS in rapid assessment and change detection of natural resources like Forest/ Tree

cover over very large landscapes, where the conventional methods of manual survey and assessment would have taken years together and would have defeated the very purpose of monitoring on real time basis (Ekwal 2011). In the present day scenario, where deforestation/ degradation of forest cover in the developing countries have assumed paramount interest in the context of climate change, frequent and periodic monitoring of greening / afforestation and forest conservation programmes at state/ country level through people's participation, can be made possible only through RS / GIS technology which is also the most reliable and cost- effective method.

\section{ACKNOWLEDGEMENT}

The authors would like to thank West Bengal Forest Department and the forest officials of West Bengal Forest Directorate at various levels for providing all support to carry out the study.

The authors are also greatful to Techno India University for providing hardware and software support for digital image processing in their Forest and Environmental Science Research Vertical. 


\section{REFERENCES}

[1] India State Forest Report, 1989. Published by Forest Survey of India, Ministry of Environment \& Forest, Government of India.

[2] Sudhakar S., Krishnan N., Ramana I.V., Das P.K., Raha A.K., 1992. Forest Cover using IRS-IA LISS II data. Asian Pacific Remote Sensing Journal, 4(2), 25-30.

[3] India State Forest Report, 1995. Published by Forest Survey of India, Ministry of Environment \& Forest, Government of India.

[4] Sudhakar S., Sengupta S., Venkata R.I., Raha A.K., Bardhan R.B.K., 1996. Forest Cover Mapping in West Bengal etc. International Journal of Remote Sensing, 17(1), 29-42.

[5] Raha A.K., Sudhakar S., Prithviraj M., 1997. Forest Change Detection Studies and Wetland Mapping through Digital Image Processing of Indian Remote Sensing Satellite Data.

[6] Guhathakurta P., Roy S., 2000. In: Joint Forest Management in West Bengal - A Critique (Published by Forest \& Wildlife Division, WWF India), pp 1-172.

[7] India State Forest Report, 2005, Published by Forest Survey of India, Min. of Environment \& Forest, Government of India.

[8] Raha A.K., 2007. Real time Forest cover mapping using IRS - P6 data. Paper presented in Second ESRI Asia - Pacific User conference, 18-19 Jan 2007, New Delhi, India.

[9] Yichun X., Zongyao S., Mei, Y., 2008. Remote sensing imagery in vegetation mapping review. Journal of Plant Ecology, 1(1), 9-23.

[10] State Forest Report, West Bengal, 2010-11. Chapter 3 , Published by Forest Directorate, Government of West Bengal, pp 14-15.

[11] Ekwal I., 2011. Mapping of Landscape Cover Using Remote Sensing and GIS in Chandoli National Park, India. Momona Ethiopian Journal of Science, 3(2), 78-92.

[12] India State of Forest Report, 2011, Chapter 9.29, Published by Forest Survey of India, Dehradun, India, pp 241- 246

[13] India State of Forest Report, 2013, Chapters 2 and 9, Published by Forest Survey of India, Dehradun, India. 